\title{
First record of the straight-billed reedhaunter (Limnoctites rectirostris Gould, 1839) for the state of Paraná, Brazil
}

\author{
João Vitor Perin Andriola ${ }^{1 *}$ \\ Amanda Perin Marcon ${ }^{2}$ \\ ${ }^{1}$ Universidade Regional Integrada do Alto Uruguai e das Missões - Campus de Erechim \\ Laboratório de EcoFauna, Departamento de Ciências Biológicas \\ Avenida Sete de Setembro, 1621, CEP 99709-510, Erechim - RS, Brazil \\ ${ }^{2}$ Universidade Federal do Rio Grande do Sul, Instituto de Biociências, Departamento de Zoologia \\ Avenida Bento Gonçalves, CEP 91540-000, Porto Alegre - RS, Brazil \\ * Corresponding author \\ jvandriola@gmail.com
}

Submetido em 24/08/2017

Aceito para publicação em 26/01/2018

\section{Resumo}

Primeiro registro de arredio-do-gravatá (Limnoctites rectirostris Gould, 1839) para o estado do Paraná, Brasil. O arredio do gravatá habita banhados com presença de gravatás (Eryngium spp.) e sua distribuição abrange o Uruguai e o Brasil, onde se acreditava estar restrito aos estados de Rio Grande do Sul e de Santa Catarina. Neste estudo, relatamos o primeiro registro da espécie no estado do Paraná, na cidade de Palmas, aumentando a já conhecida distribuição da espécie e a lista de aves do estado. Destacamos também a importância dos estudos para a conservação das espécies no estado.

Palavras-chave: Banhados; Ecologia; Eryngium; Expansão de distribuição; Furnariidae

\section{Abstract}

The straight-billed reedhaunter inhabits marshes that contain eryngos (Eryngium spp.) and is distributed from Uruguay to Brazil, where it was thought to be restricted to the states of Rio Grande do Sul and Santa Catarina. In this study, we report the first record of the species for Paraná State, in the city of Palmas, increasing the known distribution of the species and the state's list of birds. We also highlight the importance of studies to the conservation of the species in the state.

Key words: Ecology; Eryngium; Expansion of distribution; Furnariidae; Marsh 
The straight-billed reedhaunter (Limnoctites rectirostris Gould 1839) is the only species of the genus Limnoctites. It is a southern swamp species (SIGRIST, 2014), inhabiting marshes with a predominance of eryngos (Eryngium spp.) in field areas from sea level to 1,100 m elevation (ICMBio, 2013). Its diet consists of arthropods, which it captures while jumping constantly and hiding among the eryngos (GERZENSTEIN; ACHÁ VAL, 1967). The species is distributed in southern and southeastern Uruguay, Buenos Aires and Entre Rios in Argentina, and southern Brazil (OLSON et al., 2005). Its global conservation status is considered to be Near Threatened (IUCN, 2017) and in the state of Santa Catarina it is considered to be Critically Endangered (CONSEMA, 2011).
On 12 July 2017 an individual of straight-billed reedhaunter was recorded (Figure 1) in the city of Palmas, Paraná State (26³4'31.96”'S; 5144'42.87’'W). The bird was vocalizing on the leaf of a giant sea holly eryngo (Eryngium pandanifolium Cham. \& Schltdl) in a place characterized as a small marsh with a conspicuous amount of eryngos. Around the marsh there are many monoculture crops (oats and soybeans) and plantations of Pinus spp., which are threats to the natural habitat of the species (BRUMMELHAUS et al., 2012). The locality is less than $8.5 \mathrm{~km}$ from Refugio de Vida Silvestre dos Campos de Palmas, an important conservation unit of native fields in the region. A detailed observation was made, as well as photographs and a recording of the individual's vocalization, to correctly identify the species.

FIGURE 1: Individual of straight-billed reedhaunter (Limnoctites rectirostris) recorded in Palmas, Paraná. Author: Andriola, J.V.P. 2017.

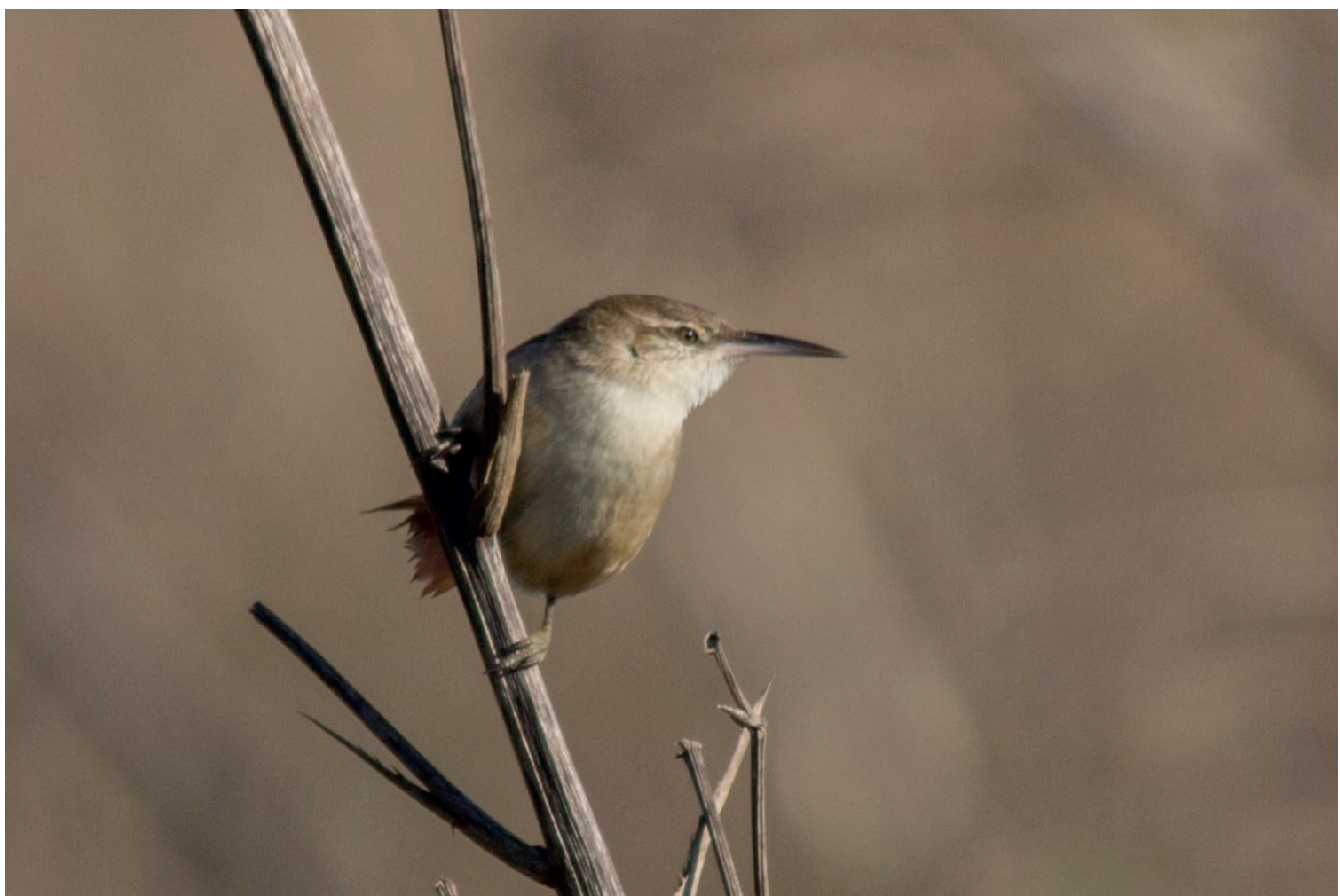


FIGURE 2: Distribution map of the straight-billed reedhaunter (Limnoctites rectirostris) in the South Region of Brazil, highlighting Palmas and Água Doce as the most northern records known for this species. Author: Marcon, A.P. 2017.

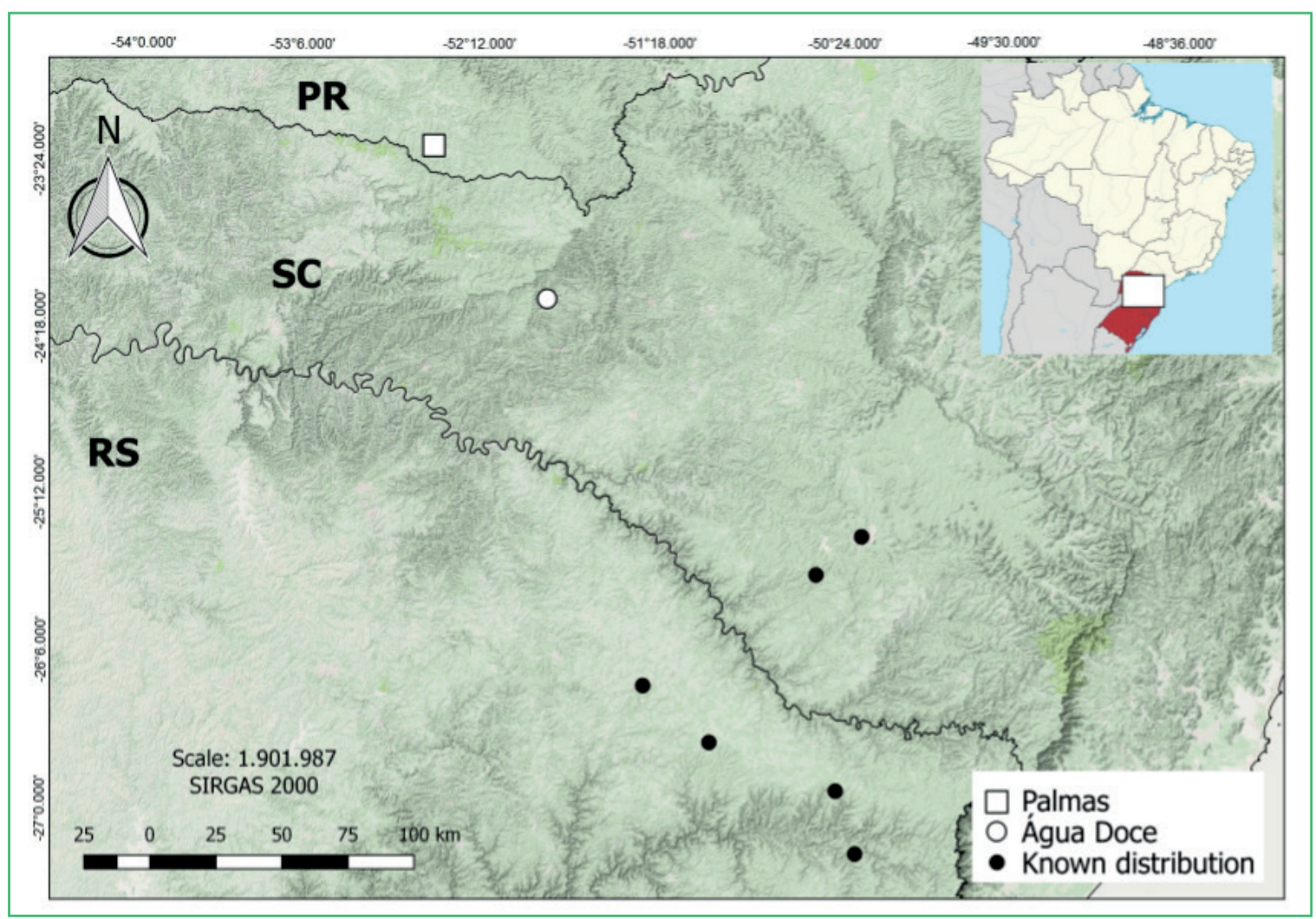

In Brazil, it was believed that the species occurred only in the states of Rio Grande do Sul and the southernmost part of Santa Catarina (HBW, 2017), and was theoretically absent in the state of Paraná (SCHERER-NETO et al., 2011), but this study verified the presence of the species for the first time in Paraná. In Santa Catarina, most records are from the region of Campos de Cima da Serra, in the southern part of the state (WIKIAVES, 2017). However, the species has also been recorded in the territory of Água Doce, on the border with Paraná in the northern part of the state (REPPENING, 2011), which was, until now, the most northern record (Figure 2). The record reported in this work increases the number of species known to occur in the state of Paraná and also increases the known distribution of the species in the country. Near the locality of the record, there are many marshes of different sizes, boosting a possible resident population of the species in Paraná. This demands additional studies on the conservation status of this bird in the state, considering major threats such as silviculture, monoculture and swamp drainage (BRUMMELHAUS et al., 2012).

\section{References}

BRUMMELHAUS, J.; WEBER, J.; PETRY, M. V. A influência da fragmentação da mata ciliar sobre a avifauna na Bacia Hidrográfica do Rio Caí, Rio Grande do Sul. Neotropical Biology and Conservation, São Leopoldo, v. 7, n. 1, p. 57-66, 2012.

CONSEMA - CONSELHO ESTADUAL DO MEIO AMBIENTE. Resolução no 02/2011 - Reconhece a lista oficial de espécies da fauna ameaçadas de extinção no estado de Santa Catarina e dá outras providências. Florianópolis: CONSEMA/SDS, 2011.

GERZENSTEIN, E.; ACHÁVAL, F. Nuevos datos sobre Limnoctites rectirostris. El Hornero, Buenos Aires, v. 10, n. 4, p. 307-314, 1967.

HBW - HANDBOOK OF THE BIRDS OF THE WORLD. Straight-billed Reedhaunter (Limnoctites rectirostris). 2017. Available at: <http://www.hbw.com/species/straight-billedreedhaunter-limnoctites-rectirostris>. Access in: 23 July 2017.

ICMBio. Plano de ação nacional para a conservação dos Passeriformes ameaçados dos Campos Sulinos e Espinilho. Série Espécies Ameaçadas, no 31. Brasília: ICMBio, 2013. 213 p. 
IUCN - INTERNATIONAL UNION FOR CONSERVATION OF NATURE. Limnoctites rectirostris. 2017. Available at: <http:// www.iucnredlist.org/details/22702652/0>. Access in: 23 July 2017.

OLSON, S. L.; IRESTEDT, M.; ERICSON, P. G. P.; FJELDSÅ, J. Independent evolution of two Darwinian marsh-dwelling ovenbirds (Furnariidae: Limnornis, Limnoctites). Ornitologia Neotropical, Montreal, v. 16, p. 347-359, 2005.

REPPENING, M. [WA302177, Limnoctites rectirostris Gould, 1839]. 2011. Available at: <http://www.wikiaves.com/302177>. Access in: 12 July 2017.
SCHERER-NETO, P.; STRAUBE, F. C.; CARRANO, E.; URBENFILHO, A. Lista das aves do Paraná. Hori Cadernos Técnicos no 2. Curitiba: Hori Consultoria Ambiental, 2011. 130 p.

SIGRIST, T. Guia de campo Avis Brasilis - Avifauna brasileira. São Paulo: Avis Brasilis, 2014. 608 p.

WIKIAVES. Arredio-do-gravatá. 2017. Available at: <http:// www.wikiaves.com/arredio-do-gravata>. Access in: 23 July 2017. 